\title{
Millimeter of Mercury per Second
}

National Cancer Institute

\section{Source}

National Cancer Institute. Millimeter of Mercury per Second. NCI Thesaurus. Code C73764.

A rate of inflation or deflation of a manometric device based on the unit of pressure equal to $133,332 \mathrm{~Pa}$ or 1.316E10-3 standard atmosphere during period of time equal to one sixtieth of a minute. 